\title{
AESTHETICAL AND EMOTIONAL EFFECTS OF MATERIAL ON CLOTHING DESIGN*
}

\author{
Pınar GÖKLÜBERK ÖZLÜ \\ Prof.Dr., Gazi University, Art and Design Faculty, Department of Fashion Design. \\ pinarozlu@gmail.com \\ Serap DENGIN SEVINIR \\ Res.Asist. Gazi University, Art and Design Faculty, Department of Fashion Design. \\ serapsevinir@gmail.com
}

\begin{abstract}
The purpose of this research is to analyze the aesthetical and emotional effects of the materials with similar sensory properties and the clothing with the same clothing type and model which were made of such materials, among the consumers. The material of the research are four different clothing fabrics (artificial leather, chiffon, denim, and combed cotton). Half-circle skirt model was produced from each fabric in accordance with sizes of $1 / 2$ scale dress form. The data of research were collected with aesthetic effect measurement tool, emotional response measurement tool and interview forms in two stages. In the first stage, consumer attitudes towards to the fabrics are examined. In the second stage, consumer attitudes towards to relationship between the fabric and the model in the second stage are examined. According to research results, artificial leather and half-circle skirt had the highest level with regard to both aesthetics and emotional effects whereas combed cotton fabric and half-circle skirt had the lowest level. One of the important results of the research is that the levels of aesthetic and emotional effects which come up during the two-dimensional evaluation of the fabrics change when the fabrics turned into a model. Another significant result of the research was that the expressions of the participants were usually based on the personal experiences and the structural features of the fabrics during the evaluations of the fabrics and the models.
\end{abstract}

Keywords: Clothing design, Material, Fabric, Emotional effect, Aesthetics effect.

\section{GIYSI TASARIMINDA MALZEMENIN ESTETIK VE DUYGUSAL ETKISI}

\section{ÖZ}

$\mathrm{Bu}$ araştırmanın amacı, benzer duyusal özelliklere sahip malzemelerin ve bu malzemelerden üretilen aynı tür ve modeldeki giysilerin tüketicilerde uyandırdığı estetik ve duygusal etkilerini incelemektir. Araştırmanın materyali, dört farklı giysilik kumaştır (suni deri, şifon, denim ve penye). Araştırmada her bir kumaştan $1 / 2$ ölçekli giysi formuna uygun kloş etekler üretilmiştir. Araştırmanın verileri, estetik etki ölçüm aracı, duygusal tepki ölçüm aracı ve görüşme formları ile toplanmış ve veri toplama işlemi iki aşamada gerçekleştirilmiştir. İlk aşamada, tüketicilerin kumaşlara yönelik tutumları; ikinci aşamada ise kumaş ve model arasındaki ilişkiye yönelik tutumları incelenmiştir. Araştırma sonuçlarına gore; deri kumaş ve kloş eteğin estetik ve duygusal etki düzeyleri en yüksekken; penye kumaş ve kloş eteğin etki düzeyi en düşüktür. Araştırmanın önemli sonuçlarından birisi, kumaşlar modele dönüştüğü zaman kumaşların iki boyutlu değerlendirilmesinde ortaya çıkan estetik ve duygusal etkilerinin değişmesidir. Diğer önemli bir sonuç ise kumaş ve modellerin değerlendirilmesi sırasında katılımcı ifadelerinin kişisel deneyimlere ve kumaşların yapısal özelliklerine dayanmasıdır.

Anahtar kelimeler: Giysi tasarımı, Malzeme, Kumaş, Duygusal etki, Estetik etki.

\footnotetext{
${ }^{*}$ The part of this research was presented in oral paper at $6{ }^{\text {th }}$ World Conference on Design and Arts WCDA-2017, Zagreb; but not published in the proceedings book.
} 


\section{INTRODUCTION}

When shopping for clothes, selection process involves touching the fabric of the garment and trying on clothing. In this process, a complex multi-sensory, emotional, and cognitive experience takes place. A memory is stirred an emotion feeling, and association is evoked and a decision is made, an impression becomes embossed in the mind. Consequently, decisions and motivations are based on anticipated reality of preference, personality, emotion, and moods (Moody, and et all., 2001).

The fabric, which is both a visual and a tactile element of the clothing design, is very important for the overall appearance and aesthetic success of the clothing desired to be created (Seivewright, 2013: 128). General view of a clothing is directly affected by the characteristics of the fabric of which it is made; different fabrics reveal different shapes and effects (Aldrich, 2013: 8). A fabric makes distinct impacts on each model. Besides, when the fabric of a model changes, the impact of that model varies accordingly.

Product materials determine the range of function, durability, cost, and user experience. The aspects of materials can be for the most part categorized in two groups, namely the technical aspects and the user-interaction aspects. While the technical aspects of materials define how the product will be manufactured and how it will function, the user-interaction aspects are those that influence the usability and personality of a product (van Kesteren, and et all., 2007b,: 41). In the selection process of materials, not only functional aspects of materials are considered, also user-interaction aspects such as aesthetics, perceptions and emotions are considered (van Kesteren, Stappers, \& de Bruijn, 2007a: 1).

Deciding on the ideal fabrics to make the clothing as expected is a difficult and vital step for designers (Aldrich, 2013: 25). When designers research to transform their design into a third dimension in the design process, aims to select the most suitable material from a list candidate materials. Many scholars in the field of materials and design put more emphasis on the technical properties of materials, manufacturability possibilities, economical requirements, availability, and environmental issues in material selection. However, in product design materials should not only fulfill technical requirements but also appeal to the user's senses (Karana, 2009: 69). The focus in the modern society entered the cultural and spiritual consumption times, paying more attention to emotional value, that is, the times of emotional consumption times. Consumers pay more attention to the psychological values of products, the purpose of consumption is not only the functional properties of products, but a sense of satisfaction in the pursuit of fashion and the ideal self-demand (Weihua, 2009: 1524). There is growing interest and recognition for the more intangible side of product design, which has lead researchers and practitoners to put more emphasis on issues such as pleasure in products, product semantics, emotions in design (Karana, and et all., 2009: 2778).

According to Nkanishi and Niwa (2001: 251), the beauty of the appearance of clothing is one of the most important factors determining the quality of garments. This includes the color, pattern and texture of a fabric surface, the fitness of a garment to the wearer's body shape, tailoring technique, and the silhouette. As a the concept, beauty is a qualification that arouses aesthetic pleasure, enthusiasm, and sense of pleasure (Turkish Language Society). Aesthtics is the branch of philosophy that deals with sensory judgments of beauty and good taste. According to Gerŝak's research (2004: 239), aesthetic appeal is one of the five major requirements that fabrics must meet. Aesthetic appeal is about how a textile product can assure aesthetic appearance. According to van Gorp and Adams (2012: 86), "aesthetics" doesn't refer just to visual appearance, but also to judgments of what makes a sound, feeling, smell, or taste appealing. In this research, "aesthetics" concept focuses on "how to perceive the visual and tactile properties resulting from structural organization of certain materials (fabrics) and the products producted by those materials.

\section{The purpose of research}

The purpose of this research is to analyze the aesthetical and emotional effects of the materials and the clothing with the same clothing type and model which were made of such materials, among the 
consumers. In the research, answers of the following questions were sought based on the question "what is the effect of the material (fabric) with regard to perceived aesthetics and emotional effects of the clothing?" to reach the aim of the research.

1. What are the aesthetical effects of the fabric and the relationship between the fabric and the model on the consumers?

2. Which emotional reactions of the consumers are caused by the fabric and the relationship between the fabric and the model with regard to physical appearance?

3. Do the levels of aesthetical effects on the consumers change when the fabric is turned into a model?

4. Do the levels of emotional reactions of the consumers change when the fabric is turned into a model?

\section{The foundation of the present research}

In today's product consumption, it is aimed that the fabrics to be used in clothing production can positively influence to the consumer's senses rather than fulfilling functional requirements. According to Khalid and Helander (2006: 197), the success of a product in the marketplace may be determined by its aesthetic appeal, the pleasure it creates, and the satisfaction it brings to the custumer. However, while the designers easily have access to various information including the technical specifications of the materials, it is difficult to reach reliable sources of information about the aesthetic and emotional effects that materials evoke in the consumer, in the design research process. For this reason, the researches in this area is considered as important.

It is difficult to measure and analyse the emotional values of fabrics that can be experienced with tactile and visual perceptions in opposite to technical and functional properties such as abrasion resistance, colour fastness, and dirt repellency (Bang, 2007: 2). Understanding the link between emotional response and design/design components is particularly important because of the critical role that emotions often play in consumers' decision making (Kumar \& Garg, 2010: 486). Emotions are often triggered by products. Khalid and Helander (2006: 204) express that emotion is "one of the strangest differentiators in user experience". For this reason, the designers have to consider the concept of emotion at every stage of the design process.

There are various researches investigating the relationship between the mechanical-technical properties of fabrics and the appearance of clothes (Gerŝak, 2002; Gerŝak, 2003; Gerŝak, 2004; Nkanishi \& Niwa, 2001). However, any research has been not reached which deals with the aesthetic and emotional effects that arised out of fabric and fabric-model relation, by excluding the technical features of the fabrics as a textile material.

\section{MATERIAL AND METHOD}

\section{Method of research}

Research model is a case study as part of the qualitative research with respect to the methods to be applied to solve the research problem. Case study is a research model which discusses an actual fact in own reality, do not have clear verges between the fact and the content and is used when there are multiple data sources (Yıldırım \& Şimşek, 2011: 277). Research technique is the state analysis which is a type of the case study and analyzes a case from different perspectives (Büyüköztürk, and et all. 2014: 249).

\section{Participants}

Participants of the research are nine Turkish women consumers who studying at Fashion Design Department of Art and Design Faculty of Gazi University. Four of the participants are doctoral students, the rest of their are graduate students. Their ages range from 23 to 34 years.

\section{Material/Stimuli}


The material of the research (Table 1) is "artificial leather, chiffon, denim, and combed cotton" which are four different clothing fabrics. This fabrics was determined according to their structural characteristics "thinness and draping" in terms of their visual and tactile properties. All fabrics are navy blue so that the color factor is not perceptually guiding. Half-circle skirt model was produced from each fabric in accordance with sizes of $1 / 2$ scale dress form (mannequin). The skirts was dressed in dress forms.

Table 1. Material of the research
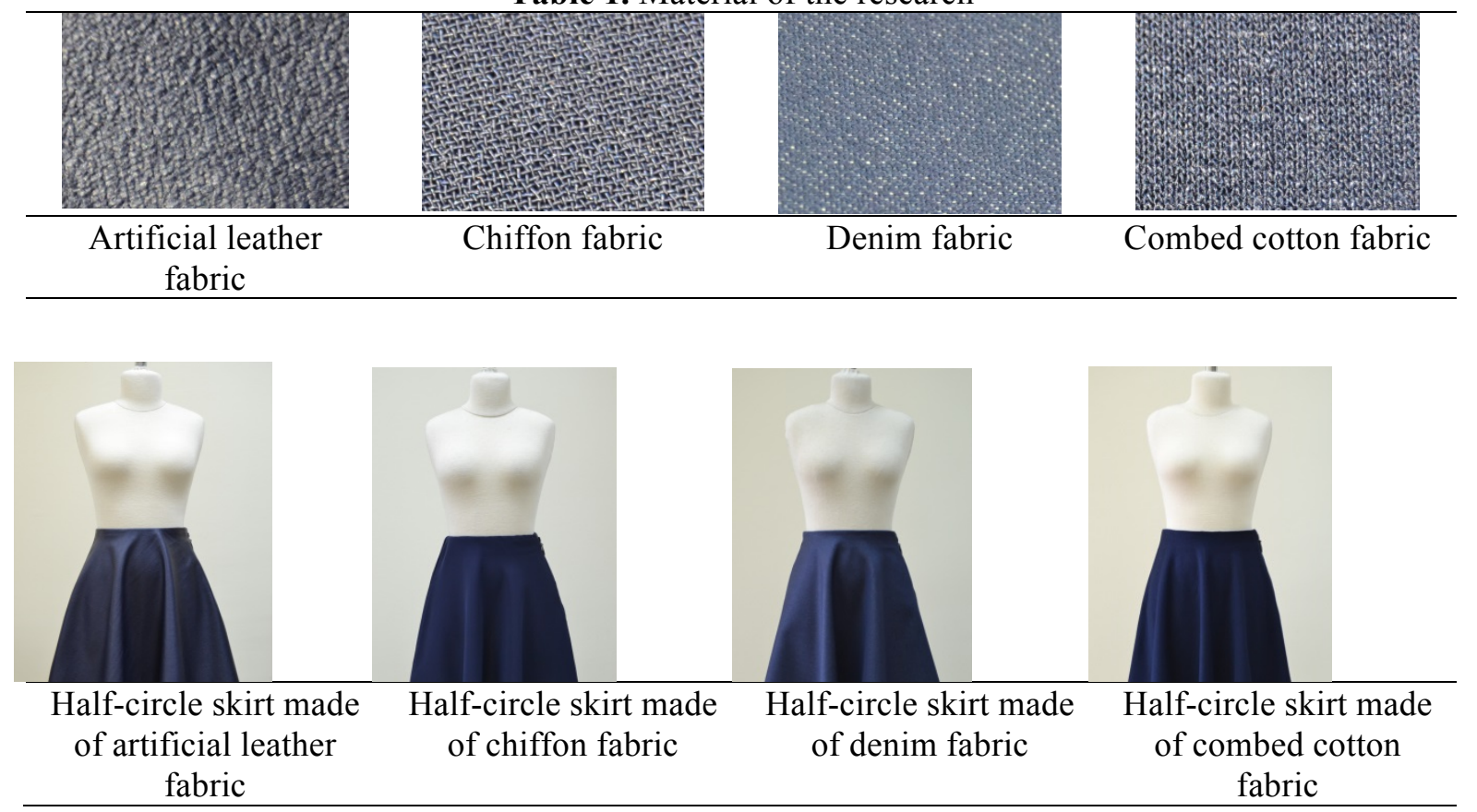

\section{Data collection}

Three different data collection tools were used in the research. These are aesthetic effect measurement tool, emotional response measurement tool and structured interview form. In the organization of scale expressions that constituted in order to measure effects of fabrics' general characteristics and fabricmodel relation on consumers were benefited from expressions that developed/used in different researches (Blijlevens, and et all., 2017; Kumar \& Garg, 2010; Morganosky \& Postlewait, 1989). The aesthetic effect is handled at two levels; fabric and fabric-model relation. At the fabric level, the expressions in the aesthetic effect measurement tool are "beautiful (güzel), attractive (çekici), chic (ş1k), nice to see (bakma hissi hoş), nice to touch (dokunma hissi hoş), want to wear (giymek isteme)". At the fabric-model relation level, the expressions in the aesthetic effect measurement tool are "beautiful (güzel), attractive (çekici), chic (şık), nice to see (bakma hissi hoş), wearable (giyilebilir), want to have (sahip olmak isteme)". Participants were asked to rate the expressions contained in the aesthetic effect measurements instruments as “" $0,10,20,30,40$ " points. The scoring is done separately for each fabric and model.

Desmet's (2002) product emotions measurement tool (Figure 1) was used to measure emotional response resulting from appearance composed of fabric and fabric-model relationship. Emotion measurement tool which was developed to measure the emotions awakened by the physical appearances of the products and comprises seven negative and seven positive emotional expressions provide a profile about all emotions that may be aroused by the physical appearances of the products (Desmet, 2002: 65). The participants are requested to mark their emotional reactions which are caused by the fabric and the relationship between the fabric and the model, on the measurement tool for product-related emotions according to facial and body expressions. 

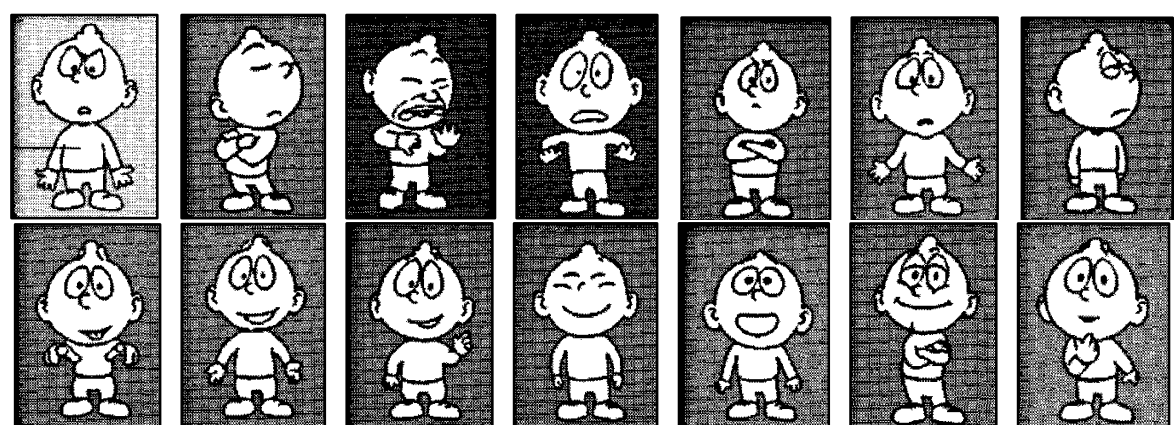

Figure 1. The product emotions measurement tool (Desmet, 2002)

Negative emotions: Indignation, contempt, disgust, unpleasant surprise, dissatisfaction, dissapointment, boredom.

Positive emotions: Desire, pleasant surprise, inspiration, amusement, admiration, satisfaction, fascination. (left-to-right).

An interview was made with the participants to reveal the reasons behind that the relevant fabrics and the products made of such fabrics are liked or not liked, and to determine the theme under which these reasons can be grouped according to the fabric. The interview questions about the fabrics and the relationship between the fabric and the model were as follows, respectively: "Why did/did not you like this fabric (artificial leather, chiffon, denim, and combed cotton)?" and "Why did/did not you like the model of the skirt made of this fabric (artificial leather, chiffon, denim, combed cotton)?"

Evaluation of the research materials was not restricted to a specific context such as intended use and place of use etc. and general attitudes of the consumers towards the stimulants were focused. The research was made up of two stages. The participants were taken to research area one by one. In the first stage, fabrics were presented to participants and the scales and interview questions were asked to manifest their approaches regarding the aesthetical AND emotional effects of the fabrics. In the second stage, $1 / 2$ scaled mannequins were dressed with the models of skirts which were made of the relevant fabrics and shown to the participants. The scales and interview questions were asked to manifest their approaches regarding the aesthetical and the emotional effects that emerged with the relationship between the fabric and the model. Collecting data for each participant took about 20 minutes. Voice and written records of the interviews were generated.

\section{Data analyse}

The points of the participants about each fabric and model which were measured by the measurement tools for aesthetical effect were converted to scores. The scores were obtained by calculating the average of the total points which were given by the participants for each fabric and the model of skirt made of the fabrics. In the evaluation of the average scores with regard to aesthetical effect, the following score intervals were used: 0-10 (not prefer), 11-20 (prefer), 21-30 (like), 31-40 (like and want to own). Points and the average scores were calculated manually.

In the measurement tool for emotional value, emotional reactions of the participants about each fabric and each model were expressed in writing with regard to their meaning. Emotional reactions that were sorted according to their frequency were given in the cross tab. Analyses were performed manually.

The notes and voice records generated during the interview which was conducted to understand the reasons behind that the fabrics and the relationship between the fabric and the model are liked or not liked were written again and made ready for the analysis. The outstanding opinions of each participant 
were detected using his/her statements about the fabric and the model and the similar opinions were grouped by forming common themes.

\section{RESEARCH FINDINGS \\ Aesthetical effect}

Aesthetical effect was discussed at two levels: general view of the fabrics and the relationship between the fabric and the model. Similarly, research findings were presented at two levels: the aesthetical effect of the general features of the fabrics and the aesthetical effect of the relationship between the fabric and the model.

\section{Aesthetical effecs of the fabric}

The fabric with the highest average score in terms of the aesthetical effect is the artificial leather with a score of 32. Artificial leather fabric is in the category of "like and want to own" and has a score interval of 27 (min.) - 37 (max.).

Chiffon has the second highest average score. The score interval and average score of the chiffon fabric are 24-31 and 27.5, respectively. Chiffon is categorized as "like" with this score.

Denim fabric ranks third with the scores of 16 (min.) and 32 (max.). Average score of the denim corresponds to 24 , thus putting the fabric in the category of "like".

The lowest average score in terms of the aesthetical effect belongs to combed cotton which has 14.5. Its score interval is $7-21$, so combed cotton is categorized as "prefer".

\section{Aesthetical effect of the relationship between the fabric and the model}

The model with the highest average score in terms of the relationship between the fabric and the model is half-circle skirt that is made of the artificial leather fabric. Artificial leather half-circle skirt ranks first in terms of the aesthetical effect with the minimum and maximum scores of 32 and 38, respectively. This model is in the category of "like and want to own" with an average score of 36 . Denim half-circle skirt has the highest second score with regard to aesthetical effect and its score interval corresponds to 22-31. Average score of the denim half-circle skirt is 26.5, thus being evaluated in the category of "like". The third rank belongs to half-circle skirt which is made of chiffon fabric with the scores of 19 ( $\min$.) and 29 (max.). The average effect level of the chiffon half-circle skirt is 24 , so this product is categorized as "like".

Half-circle skirt made of combed cotton has the lowest average score in terms of the relationship between the fabric and the model. Score interval and average score of the combed cotton half-circle skirt are $8-28$ and 18, respectively. With this score, the model is evaluated in the category of "prefer".

Emotion statement associated with the fabric and the relationship between the fabric and the model Emotion statement is discussed at two levels as follows: general view of the fabrics and the relationship between the fabric and the model. Artificial leather and denim fabrics aroused the highest number of positive emotions among the participants whereas the highest number of negative emotions were aroused by the combed cotton fabric. Considering the emotional reactions of the participants to the relationship between the fabric and the model, it was seen that artificial leather and denim fabrics created the highest number of positive emotions and the chiffon fabric had the lowest positive emotion (Table 2). 
Table 2. Emotion statement associated with the fabric and the relationship between the fabric and the model

\begin{tabular}{|l|l|l|l|l|}
\hline & Artificial leather & Chiffon & Denim & Combed cotton \\
\hline & Pleasant surprise & Pleasant surprise & Amusement (3) & Boredom (3) \\
& $(4)^{*}$ & $(2)$ & Inspiration (3) & Contempt (2) \\
& Amusement (2) & Admiration (2) & Satisfaction (2) & Satisfaction (2) \\
& Fascination (2) & Amusement & Fascination & Dissatisfaction \\
Fabric & Satisfaction & Fascination & Pleasant surprise & Amusement \\
& Admiration & Satisfaction & Boredom & Inspiration \\
& Desire & Desire & & \\
& Dissapointment & Boredom & & \\
& & Disgust & & \\
\hline & Inspiration (2) & Amusement & Amusement (3) & Boredom (3) \\
& Amusement (2) & Desire & Pleasant surprise & Contempt (2) \\
& Pleasant surprise & Pleasant surprise & (2) & Fascination (2) \\
Relationship \\
between of \\
fabric and \\
model & (2) & Contempt & Inspiration (2) & Amusement \\
& Admiration (2) & Dissapointment & Admiration & Satisfaction \\
& Indignation & Indignation & Admiration & Disgust \\
& Fascination & Dissatisfaction & Satisfaction & \\
& Desire & Boredom & Contempt & \\
& & Disgust & Boredom & \\
\hline
\end{tabular}

*Frequency

\section{Reasons behind that the fabrics are liked/not liked}

During the interviews with the participants, any negative attitude towards the leather fabric was not observed and all participants expressed their liking. Reasons behind that artificial leather fabric is liked and preferred are the structural features of the fabric such as softness, brightness and lightness, and the image it reflects. Furthermore, its usefulness and its capability to protect shape are among the reasons of liking with respect to ease of use.

Reasons behind that the chiffon fabric is liked/not liked are the same structural features of the fabric. While several participants express touching, fineness, transparency and drape of the fabric as positive features, the same features were given as the reasons of not liking by the participants. Moreover, the other negative features about the chiffon fabric are related to the structural features such as not being flexible and causing sweating.

No negative expression about denim fabric was reported in the interviews. Reasons behind that the denim fabric is liked/not liked are comfort of use, long life time and the frequent use in daily life due to above features. Additionally, fineness, drape and clarity of the denim fabric which are used in the research are the other reasons of liking.

Combed cotton created the highest number of negative opinions among the other fabrics. Reasons behind that combed cotton fabric is not liked are related to discomfort of use and contain quick deformation, sticking to body, revealing the underwear and causing difficulty in walking. The positive aspects of combed cotton fabric are its soft touching which is suitable for daily home wear and its comfort due to being flexible. 
Table 4. Themes associated with the reasons behind that the fabrics are liked/not liked

\begin{tabular}{|c|c|c|c|c|}
\hline & Artificial leather & Chiffon & Denim & Combed cotton \\
\hline Positive & $\begin{array}{l}\text { - Structural } \\
\text { features } \\
\text { - Ease of use } \\
\text { - Image it reflects }\end{array}$ & $\begin{array}{l}\text { - Structural } \\
\text { features }\end{array}$ & $\begin{array}{l}\text { - } \text { Comfort of use } \\
\text { - Long life time } \\
\text { - Structural } \\
\text { features } \\
\end{array}$ & $\begin{array}{l}\text { - } \text { Comfort } \\
\text { - Soft touching }\end{array}$ \\
\hline Negative & ------ & $\begin{array}{l}\text { - Structural } \\
\text { features }\end{array}$ & ------- & $\begin{array}{l}\text { - Deformation } \\
\text { - Discomfort of } \\
\text { use }\end{array}$ \\
\hline
\end{tabular}

Reasons behind that the models (relationship between the fabric and model) are liked/not liked

Half-circle skirt which is made of the artificial leather fabric was the first and most-riveting model over the course of the interviews with the participants. The artificial leather fabric was usually expressed as attention-grabbing due to its brightness and light - shadow effect and clear posture of its model despite having less drapes. Only a negative statement about it was made. The reason of not liking was a conflict in the meaning "not establishing a link between the artificial leather fabric which reflects a strong image and the half-circle skirt model with romantic flounces".

Half-circle skirt made of chiffon fabric was the model about which the highest number of negative statements were made. Reasons of not liking the chiffon half-circle skirt is related to the conditions of use such as having many drapes and seeming weak, movement restriction and not being suitable for the underside clothing. Furthermore, being unsuitable for the style of the person is another reason. The number of reasons of liking is low and contains the elegant view of the fabric and the well-matched relationship between the fabric and the model.

Similar to artificial leather half-circle skirt, denim half-circle skirt was the model with the highest number of positive opinions. Reasons of liking are having a comfortable and young appearance and the general posture.

Half-circle skirt made of combed cotton was the product about which the highest number of negative statements were made. Reasons of liking and not being preferred are insufficient comfort of use during movement, sticking to body and revealing the underwear. Besides, the uses think that the fabric reflects a childish image due to having many drapes. On the other hand, the reasons of liking are being comfort, general posture when the user is still and the harmony between the fabric and the model.

Table 5. Themes associated with the reasons behind that the models are liked/not liked

\begin{tabular}{|c|c|c|c|c|}
\hline & Artificial leather & Chiffon & Denim & Combed cotton \\
\hline Positive & $\begin{array}{l}\text { - Structural } \\
\text { features } \\
\text { - Light - shadow } \\
\text { effect } \\
\text { - Clear posture }\end{array}$ & $\begin{array}{l}\text { - Harmony } \\
\text { between the } \\
\text { fabric and the } \\
\text { model } \\
\text { - Drape of the } \\
\text { fabric }\end{array}$ & $\begin{array}{l}\text { - Comfortable } \\
\text { appearance } \\
\text { - Sportive } \\
\text { appearance } \\
\text { - Young } \\
\text { appearance }\end{array}$ & $\begin{array}{l}\text { - Comfort } \\
\text { - Harmony } \\
\text { between the } \\
\text { fabric and the } \\
\text { model }\end{array}$ \\
\hline Negative & $\begin{array}{l}\text { - Conflict in } \\
\text { meaning }\end{array}$ & $\begin{array}{l}\text { - Structural } \\
\text { features } \\
\text { - Difficulty of use } \\
\text { - Being unsuitable } \\
\text { for the style }\end{array}$ & ------- & $\begin{array}{l}\text { - Discomfort of } \\
\text { use } \\
\text { - Image it reflects }\end{array}$ \\
\hline
\end{tabular}




\section{CONCLUSION}

Creating a satisfactory effect aesthetically requires focusing on an approach about how the components of design are processed and perceived together (Sinclair, 2015, s. 655). Today, good design and quality are not enough for meeting the needs of the consumers and competing in the market. Designers should consider the relationship between the consumer and the products. Such tendency forced to establish a new bridge between the designers and the consumers even in the design stage (Kongprasert, 2012, s. 805; Kongprasert and Butdee, 2017, s. 170).

The tendency to show emotional approach to the design which develops and continues increasingly has become critical in the academic researches. This research aimed to analyze the aesthetical and emotional effects which specific fabrics and the skirts with the same types and models that were made of these fabrics arouse in the consumers. Furthermore, change states of the aesthetical and the emotional effects created by the fabric were observed when the fabrics were shaped with the model.

According to research results, artificial leather and half-circle skirt had the highest level with regard to both aesthetics and emotional effects whereas combed cotton fabric and half-circle skirt had the lowest level. One of the important results of the research is that the levels of aesthetic and emotional effects which come up during the two-dimensional evaluation of the fabrics change when the fabrics turned into a model. For example, chiffon in model form was not liked due to various reasons and aroused negative emotions although chiffon in fabric form was liked visually and tactilely and aroused positive emotions. This point emphasized the consideration of the relationship between the fabric and the model.

Another significant result of the research was that the expressions of the participants were usually based on the personal experiences and the structural features of the fabrics during the evaluations of the fabrics and the models. At this point, the importance of the experience factor in passing judgment on a product is highlighted. Moreover, this result remarks that structural features of the materials should not be ignored as the emotional approach to clothing design is searched.

Situation analysis of this research was performed with a homogenous and a small group of consumers. If the number of participants increases and/or a similar research is conducted with a consumer group who has different demographical features, variable results and themes may be obtained. Since this research was made with a young consumer group, it is understandable that more positive attitudes to artificial leather and denim fabrics can be developed, compared to other fabrics when the apparel consumption habits of young people and the actual trends are take into account. Therefore, it is thought that even only age variable can affect the research results considerably. Moreover, similar researches can be conducted by changing the colors, figures, thickness and similar visual and tactile features of the research materials or the apparel type and/or model and their results can be evaluated comparatively.

\section{REFERENCES}

Aldrich, W. (2013). Fabrics and Pattern Cutting, UK: Wiley Publication.

Bang, A. L. (2007). "Fabrics in Function-Emotional Utility Values", Nordes Nordic Design Research Conference, Design Inquiries, 2, 1-10.

Baber, C. (1996). "Repertory Grid Theory and Its Application to Product Evaluation", Jordan P.W., Thomas B., Weerdmeester, B.A., McClelland, I.L. (Eds), Usability evaluation in industry (pp. 157165). London: Taylor \& Francis.

Blijlevens, J., Thurgood, C., Hekkert, P., Chen, L., Leder, H., \& Whitfield, T.W.A. (2017). "The Aesthetic Pleasure in Design Scale: The Development of A Scale to Measure Aesthetic Pleasure For Designed Artifacts", Psychology of Aesthetics, Creativity, and the Arts, 11 (1), 86-98.

Büyüköztürk, Ş., Kılıç Çakmak, E., Akgün, Ö.E., Karadeniz, Ş., \& Demirel, F. (2014). Bilimsel Araştırma Yöntemleri (18th ed.), Ankara: Pegem Akademy. 
Desmet, P. (2002). "Designing Emotions”. ISBN: 90-9015877-4.

Gersiak, J. (2002). "Study of the Relationship Between Fabric Mechanics and Garment Appearance Quality Level", Book of Proceedings of 1st International Textile, Clothing and Design Conference, Magic World of Textiles, Faculty of Textile Technology, University of Zagreb, Zagreb, 353-358. Gersak, J. (2003). "Investigations of the Impact of Fabric Mechanical Properties on Garment Appearance", Textile, 52 (8), 368-79.

Gerŝak, J. (2004). "Study of Relationship Between Fabric Elastic Potential and Garment Apperance Quality”, International Journal of Clothing Science and Technology, 16 (1/2), 238-251.

Karana, E. (2009). "Meaning Driven Materials Selection in Design Education”, International Conference on Engineering Design, ICED'09, 24-27 August 2009, Stanford University, USA. 69-80.

Karana, E., Hekkert, P., \& Kandachar, P. (2009). "Meanings of Materials Through Sensorial Properties and Manufacturing Processes", Materials \& Design, 30, 2778-2784.

Khalid, H.M. \& Helander, M.G. (2006). “Customer Emotional Needs in Product Design”, Concurrent Engineering: Research and Applications, 14 (3), 197-206.

Kongprasert, N. (2012). "Emotional Design Approach to Design Teak Wood Furniture", V. Kachitvichyanukul, H.T. Luong, R. Pitakaso (Eds), Proceedings of the Asia Pacific Industrial Engineering \& Management Systems Conference.

Kongprasert, N. \& Butdee, S. (2017). "A methogology for Leather Goods Design Though the Emotional Design Approach", Journal of Industrial and Production Engineering, 34 (3), 170-179.

Kumar, M. \& Garg, N. (2010). "Aesthetic Principles and Cognitive Emotion Appraisals: How Much of the Beauty Lies in the Eye of the Beholder?", Journal of Consumer Psychology, 20, 485-494.

Moody, W., Morgan, R., Dillon, P., Baber, C., \& Wing, A. (2001). "Factors Underlying Fabric

Perception", Retrieved March 06, 2017

(http://citeseerx.ist.psu.edu/viewdoc/download?doi=10.1.1.11.1811\&rep=rep1\&type=pdf).

Morganosky, M.A. \& Postlewait, D.S. (1989). “Consumers' Evaluations of Apparel Form, Expression, and Aesthetic Quality", Clothing and Textiles Research Journal, 7 (2), 11-15.

Nakanishi, M. \& Niwa, M. (2001). "Fabric Mechanical Parameters Related to the Beauty of Fabric Movement of Ladies' Garments Brought About by Human Motion”, J. Home Econ. Jpn, 52 (3), 251264.

Seivewright, S. (2013). Moda Tasarımında Araştırma ve Tasarım, İstanbul: Literatür.

Sinclair, R. (2015). Textile and Fashion Materials, Design and Technology. UK: Woodhead Publishing.

Turkish Language Society. Retrieved April, 22, 2017

(http://www.tdk.gov.tr/index.php?option $=$ com_gts\&arama $=$ gts\&guid=TDK.GTS.58fa $790 f 5$ a 1014.023 86187).

van Gorp, T. \& Adams, E. (2012). Design for Emotion. USA: Elsevier.

van Kesteren, I., Stappers, P. J., \& de Bruijn, S. (2007a). "Defining User-Interaction Aspects for Materials Selection: Three Tools", Design Inquiries, 1-10. Retrieved March 06, 2017 (http://www.nordes.org/opj/index.php/n13/article/viewFile/173/156).

van Kesteren, I. E. H, Stappers, P. J., \& de Bruijn, J. C. M. (2007b). "Materials in Products Selection: Tools for Including User-Interaction in Materials Selection", International Journal of Design, 1 (3), 41-55.

Ylldırım, A. \& Şimşek, H. (2011). Sosyal bilimlerde nitel araştırma yöntemleri (8 ${ }^{\text {th }}$ ed.), Ankara: Seçkin.

Weihua, Y. (2009). "Fashion Design in Emotional Consumption Era", IEEE 10th International Conference on Computer-Aided Industrial Design \& Conceptual Design, November 26-29, 2009, 1524-1527. Retrieved November 02, 2015

(http://ieeexplore.ieee.org/xpl/login.jsp?tp $=\&$ arnumber $=5374966 \& u r l=h t t p \% 3 A \% 2 F \% 2 F i e e e x p l o r e$. ieee.org\%2Fxpls\%2Fabs_all.jsp\%3Farnumber\%3D5374966). 